\title{
多層構造モデルによる複合施設の最適配置 OPTIMAL LOCATION OF FACILITIES COMPLEXES WITH MULTI-LAYERED STRUCTURE
}

\author{
岸本達也* \\ Tatsuya KISHIMOTO
}

\begin{abstract}
In this paper, Multi-layered Structure of facilities system and Multi-layered Facilities Location Problems that minimize the sum of travel costs are proposed. To analyze optimal location, 2 facilities complexes location problem on a segment is concerned. Optimal solution is derived analytically, and system configuration to obtain the solution on a segment and characteristics of optimal locations are investigated. Also, a heuristic method of solution is presented, which is applicable to location problem in N-dimensional Euclidean space. Through computational simulations, the effectiveness of presented algorithm is confirmed. Finally, various facilities complexes including obnoxious facilities locations with multi-layered structure are demonstrated, and their optimal locations are investigated.
\end{abstract}

Keywords : Facilities Location, Multi-layered Structure, Facilities Complexes, Obnoxious Facility, Equity, Optimization 施設配置, 多層構造, 複合施設, 迷惑施設, 公平性, 最適化

\section{1.はじめに}

現代では、異なるサービスの複合により様々なタイプの複合施 設が計画されている。単一目的の施設から多目的の多様な複合施設 の計画が進んでおり、都市はますます多様な様相を示しつつある。 そこで本研究では、多目的な複合施設の数理的な配置計画理論の構 築を目的として、施設システムの新しいモデルとして多層構造モデ ルを提案し、それに基づく最適配置の数理計画法を示し、さらに施 設システムの構成と施設の最適配置の関係について分析する。

従来、複数種類のサービスを行う施設の配置理論としてヒエラ ルキー (階級構造注(1) $)$ をも施設の計画理論が注目され、数多く の研究がなされてきた。たとえば Christaller ${ }^{1)}$ の中心地理論をルー ツとして、ヒエラルキーモデルによる施設システムが古くから検討 されており、鈴木 ${ }^{2)}$, 奥貫・岡部 ${ }^{3)}$, Döcmeci ${ }^{4}$, Fisher et al. ${ }^{5)}$ など によってそれに基づく施設配置の計画法の研究も行われてきた。し かし現在の施設システムは、必ずしも古典的で厳正なヒエラルキー モデルによって記述できるものではない。経済効率の向上のほか、 異種サービスの複合的な計画による公平性の確保、地域色のある多 様な施設計画、等々の観点から、異種サービスを提供する多様な複 合がなされており、ヒエラルキー（階級構造）には必ずしも限定さ れない複合的な施設計画が行われている。

本研究では、まず、従来のヒエラルキーモデルに限定されない、 より多様なシステム構成を許容するシステムモデルとして多層構造
モデルを提案する。多層構造モデルによって施設の多様なサービス システムの論理的な記述を可能とするとともに、合理的な施設配置 を検討するための基礎を構築する。

次に、多層構造モデルによる施設群の最適配置を分析しその性 質を明らかにする。まず単純化した問題として、1 次元の線分上の 模擬的都市に、3 種類のサービス（施設）を複合する 2 施設を配置 する単純な例題を取り上げ、その理論的最適配置を演繹的に導く。 また最適配置を線分上に見つけることが可能であるための施設シス テムの構成要件を明らかにするとともに、システム構成が変わった ときに最適配置がどう変化するのかを分析してその性質を明らかに する。

さらに、提案した多層構造モデルに基づき施設配置の計画を支 援する数理的手法として、サービス数・施設数が大きい大規模な問 題でも適用可能な発見的解法を示す。また線分上の問題における理 論的最適解との比較を通して、その解法の有効性を検証する。

最後に、施設のシステム構成と最適配置の関係にみられる性質 について 2 次元平面上の配置問題で確認するとともにその洞察を 深める。多層構造モデルは一般性のあるモデルであるので、可能性 のある全てのシステム構成について施設の最適配置を分析すること は不可能である。そのため特徵的な例として、施設の複合程度が異 なる場合、施設システムに迷惑施設注(2)を含む場合の 2 事例におい ていくつかの最適配置の計算例を示し、最適配置とシステム構成の 
関倸について考察を加える。

なお、予め本研究で用いる用語と記法を定義しておく。施設 (Facility) とは、地域において何らかのサービスを提供する拠点 を指す。したがって、施設とは建築に限るものではなく、公園や駐 車場等も施設にあたる。また建築内部の「室」も 1 機能を果たす 施設といえる。複合施設とは、複数種類のサービスを同時に提供す る施設を指す。「複合施設」には様々な形態による施設の複合が考 えられるが、2 種類以上のサービスを行う拠点（施設）を設えた拠 点を複合施設と呼ぶ。数学的記述では、施設の総数を $n$ で表し、 施設の集合を $X=\left\{X_{1}, X_{2}, . . X_{i}, . ., X_{n}\right\}$ 、施設 $X_{i}$ の座標を $\boldsymbol{x}_{i}$ と表す。サ ービスの総数をlと表し、サービスの集合を $S=\left\{S_{1}, S_{2}, ., S_{k} \ldots, S_{l}\right\}$ と表す。また、施設 $X_{i}$ で提供されるサービスの集合を $B_{i}$ と表す。 サービスを需要する住民の居場所を需要点、需要点の総数を $m$ 、 その座標をそれぞれ $\boldsymbol{y}_{j}(j=1,2, . ., m)$ と表す。また需要点 $\boldsymbol{y}_{j}$ にお けるサービス $S_{k}$ に対する需要の重みを $w_{j k}$ と表す。

\section{2. 多層構造モデルの提案}

複数のサービスを提供する施設群のサービスシステムは、Tien et al. ${ }^{6)}$ 、鈴木 ${ }^{2)}$ 、および奥貫・岡部 ${ }^{3)}$ では、包含的階級構造 (Successively Inclusive Hierarchy) と排他的階級構造 ( Successively Exclusive Hierarchy )の 2 種類のシステムモデルにおいて分類さ れ検討されている注(3)。本章ではこれらの知見を踏まえた上で、多 層構造モデルというシステムモデルを提案する。

\section{1. 包含的階級構造モデル}

「下位の施設で行われるサービスは、必ず上位の施設でも行わ れる」という記述が可能なシステムのモデルを「包含的階級構造」 と呼ぶ。つまり施設 $X_{i}$ で行われるサービスの集合 $B_{i}$ について、 $i<i^{*}$ なら $B_{i} \subseteq B_{i *}$ であることが条件である。サービスシステムの分かり 易い包含的階級構造の例を表 1 に示す。たとえば、行政サービス 施設における市役所と出張所の関係である。出張所で行われるサー ビスは、すべて市役所でも行われるが、市役所で行われるサービス の全てが出張所で行われるとは限らないから、市役所を上位施設、 出張所を下位の施設とすれば、それらの関係には包含的階級構造が ある。

\section{2. 排他的階級構造モデル}

「ある階級の施設で行われるサービスが、その他の階級の施設 では行われないようなシステムのモデルを排他的階級構造と呼ぶ。 つまり施設 $X_{i}$ で行われるサービスの集合 $B_{i}$ について $i \neq i^{\star}$ なら $\phi=B_{i}$ $\cap B_{i^{*}}$ たは $B_{i}=B_{i^{*}}$ であることが条件である。排他的階級構造の例 を表 2 に示す。たとえば、高等学校、中学校、小学校などの関係 である。これらはすべて教育施設であるが、小・中・高が異なれば サービスの対象となる人々が全く異なっており、サービス内容にお ける共通性は何もない。このような関係を排他的階級構造と呼ぶ。

\section{3. 多層構造モデル}

上記 2 種類のシステムモデルは、ヒエラルキーモデルを基本と している。システムを合理的に設計するためには非常に分かり易く、 その意味で有益である。しかし、既に述べたように、地域施設の多 様化という観点からすれば、それだけでは不十分である。現実には 施設の複合による経済効率の向上、異種サービスの複合的施設配置 による公平性の向上、地域色の豊かな施設計画などの観点から、ヒ
表 1 包含的階級構造の例

\begin{tabular}{|c|c|c|c|}
\hline \#-ビス & $S_{1}$ & $S_{2}$ & $S_{3}$ \\
\hline 施設 $X_{1}$ & 0 & 0 & 0 \\
\hline$X_{2}$ & 0 & 0 & \\
\hline$X_{3}$ & 0 & 0 & \\
\hline$X_{4}$ & 0 & & \\
\hline$X_{5}$ & 0 & & \\
\hline$\cdots$ & $\cdots$ & & \\
\hline
\end{tabular}

表 2 排他的階級構造の例

\begin{tabular}{|c|c|c|c|}
\hline サ-ビス & $S_{1}$ & $S_{2}$ & $S_{3}$ \\
\hline 施設 $X_{1}$ & & & $\bigcirc$ \\
\hline$X_{2}$ & & $\bigcirc$ & \\
\hline$X_{3}$ & & $\bigcirc$ & \\
\hline$X_{4}$ & $\bigcirc$ & & \\
\hline$X_{5}$ & $\bigcirc$ & & \\
\hline$\cdots$ & $\cdots$ & & \\
\hline
\end{tabular}

表 3 多層構造の例

\begin{tabular}{|c|c|c|c|}
\hline H-ビス & $S_{1}$ & $S_{2}$ & $S_{3}$ \\
\hline 施設 $X_{1}$ & 0 & & 0 \\
\hline$X_{2}$ & & 0 & \\
\hline$X_{3}$ & 0 & 0 & \\
\hline$X_{4}$ & 0 & & \\
\hline$X_{5}$ & 0 & & \\
\hline$\cdots$ & $\cdots$ & $\cdots$ & $\cdots$ \\
\hline
\end{tabular}

○はサービスが行われるこ とを表す（本論以下同様）。

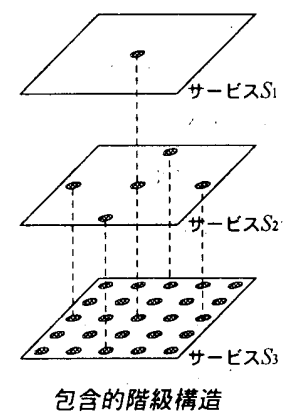

包含的階級構造
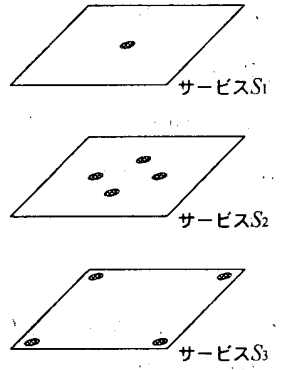

排他的階級椪造

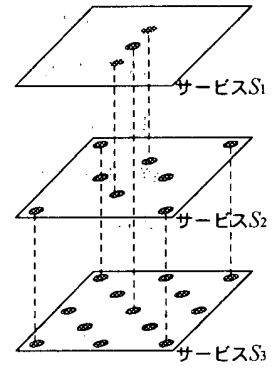

多層構造

\section{多層構造}

\section{図 1 施設システムのモデル}

エラルキーに限定されない多様な複合施設の計画が行われている。 また、現実に計画される施設の多くは複合施設であり、そのサービ ス内容に共通点もあれば相違もある。たとえば単にスポーツ施設と いっても、それらは様々なサービス施設の複合によって成立してお り、サービス内容にはアスレチックジム・テニスコート・野球場・ サッカー場・体育館・プール・スタジオなど多彩である。つまり、 スポーツ施設というカテゴリーでは同じでも、複合しているサービ スの種類にようて施設内容は異なる場合が多い。また、逆にコミュ ニティセンターと図書館、公民館などの場合は、集会室・研修室な ど、同じサービス施設を有する場合も多く、カテゴリーでは異なっ ていても施設のサービス内容には共通点が多いのが実状である。つ まり、単純に○○施設というカテゴリーで分類して計画しても、 現実のサービス内容は異なっていたり、逆に同じであったりする場 合も多く、利用者の真の利便性を考えるならば支障のあることが分 かる。利用者の真の利便性を考えるならば、計画する施設のサービ ス内容を細かく分類し、施設相互のサービス内容における共通点お よび相違点を明確にしておく必要がある。

そのような場合、施設システムを古典的なとエラルキーモデルを 用いて記述することが困難であることは容易に想像できる。より一 般的なシステムモデルを用いて記述することが必要となる。

そこで本研究では、包含的階層構造や排他的階層構造をふくむ 
一般的なシステムモデルとして「多層構造 (Multi-Layered Structure)」モデルを提案する。多層構造とは、「全ての施設では 1 種類 以上のサービスが行われている」施設システムのモデルと定義する。 多層構造によるサービスシステムの例を表 3 に示す。多層構造モ デルでは、施設相互に上位と下位の関係は必要ない。全ての施設で、 1 種類以上のサービスが行われていればよい。すなわち包含階級構 造も排他的階級構造も多層構造に含まれる(図 1)。ジスムの構 成において包含的階級構造や排他的階級構造のようにあらかじめ想 定された構造はなく、構造上の制約は何もない。一見して、このよ うに何ら制約のないモデルの提案は無意味のように思えるが、ヒエ ラルキー構造に拘らない多様なシステムを計画する場合、あるいは これまでにない精緻なシステムの計画を推進する場合には、様々な システムを記述可能とするため、このような一般化されたシステム モデルは不可欠である。また、さらにそれに基づく計画理論の枠組 みも必要であろう。次章以降では、この一般化されたシステムモデ ルである多層構造モデルの枠組みの中で、複合施設による施設シス テムの構成とその最適配置について考察していく。

\section{3. 多層的施設システムの最適配置問題}

本章では、多層構造を有する施設群の最適配置について検討す る。前章で提案した多層構造モデルの枠組みは、サービスの種類が 複数の場合の一般化であり、様々な施設配置モデルに対して適用可 能である。たとえば岸本 ${ }^{14,17,18,19)}$ で、すでに幾つかの施設配置モデ ルを提案しているが、そのいずれについてもサービスの種類を複数 として適用することは可能であろう。ただし紙面の都合があるので、 本研究では、最も基本的で歴史的にも重要な施設配置モデルの、「最 近隣の施設を利用する場合に利用距離の総和を最小とする最適配置 を求める問題 (多点のウェーバー問題)」について、多層構造によ る施設システムを適用し、以後本研究ではそれを検討していくこと とする。

最適配置問題「サービス $S_{k}$ に対する需要者が、サービス $S_{k}$ が行 われている施設の中で最近隣の施設のみを利用し、その移動費用が ユークリッド距離に比例すると仮定した場合、多層構造が所与な施 設群をそれぞれどこに配置すれば、利用者の移動費用の総和は最小 となるか。全ての需要点 $\boldsymbol{y}_{j}$ におけるサービス $S_{k}$ に対する需要者数 (需要点の重み) $w_{j k}$ を所与とする。」

移動費用の総和は、サービスに対する需要点の重み $w_{j k}$ とそのサ ービスを受けるために必要となる移動費用の積の総和で表されるの で、移動費用の総和を最小とする最適配置問題は、(1)のように定 式化される。

$$
\text { Minimize } F\left\{\boldsymbol{x}_{i}, \boldsymbol{M}_{i j k}\right\}=\sum_{i} \sum_{j} \sum_{k} \boldsymbol{M}_{i j k} w_{j k}\left\|\boldsymbol{y}_{j}-\boldsymbol{x}_{i}\right\|
$$$$
\text { subject to } \boldsymbol{M}_{i j k}=\left\{\begin{array}{lll}
1 & \text { if } & i=c(j, k) \\
0 & \text { if } & i \neq c(j, k)
\end{array}\right.
$$

$$
c(j, k)=\underset{i}{\operatorname{argmin}}\left\{\left\|\boldsymbol{y}_{j}-\boldsymbol{x}_{i}\right\|, \quad i \mid S_{k} \in B_{i}\right\}
$$

ただし $\boldsymbol{M}_{i j k}$ は需要点 $\boldsymbol{y}_{j}$ におけるサービス $S_{k}$ の需要が施設 $\boldsymbol{x}_{i}$ に割 り当てられるか否かを 0,1 の整数で表す行列で、 $\arg \min \left\{\left\|\boldsymbol{y}_{j}-\boldsymbol{x}_{i}\right\|\right\}$ で\| $y_{j}-x_{i} \|$ 最小とする添え字 $i$ が 2 以上ある場合は、任意の 1 つが選択されることとする。

\section{4. 線分上の 2 施設の最適配置と多層的施設システムの分析}

本章では、多層構造モデルをもちいた配置問題の単純な例題を 設定し、複合施設による施設システムの構成と最適配置の関係につ いて考察する。サービスシステムの構成が変化した場合に、それぞ れの施設の最適配置がどのように変化するのかを把握することは、 計画学上の有益な知見となる。ここでは便宜的に、需要点が一様に 連続して分布する線分上の模擬都市を仮定し、そこに 2 施設を配 置することとする。サービスの種類数を 3 とし、それぞれ $S_{1}, S_{2}, S_{3}$ とする。需要の重みは全ての需要点で同じと仮定し、サービス $S_{1}, S_{2}$, $S_{3}$ に対する需要点の重み $w_{1}, w_{2}, w_{3}$ の大きさをそれぞれ $\alpha, 1, \beta$ と する。また、第 1 の施設 $X_{1}$ ではサービス $S_{1}$ と $S_{2}$ を行い、第 2 の 施設 $X_{2}$ では $S_{2}$ と $S_{3}$ のサービスを行うと仮定する(つまり $B_{1}=\left\{S_{1}, S_{2}\right\}$, $\left.B_{2}=\left\{S_{2}, S_{3}\right\}\right)$ 。施設 $X_{1}$,施設 $X_{2}$ ともに複合施設である。この時の多 層構造を表 4 に示す。

表 42 つの複合施設によるサービスシステム

\begin{tabular}{|l|c|c|c|}
\hline サービスの種類 & $S_{1}$ & $S_{2}$ & $S_{3}$ \\
\hline 需要点の重み & $\alpha$ & 1 & $\beta$ \\
\hline 施設 $X_{1}$ & $\bigcirc$ & $\bigcirc$ & \\
\hline 施設 $X_{2}$ & & $\bigcirc$ & $\bigcirc$ \\
\hline
\end{tabular}

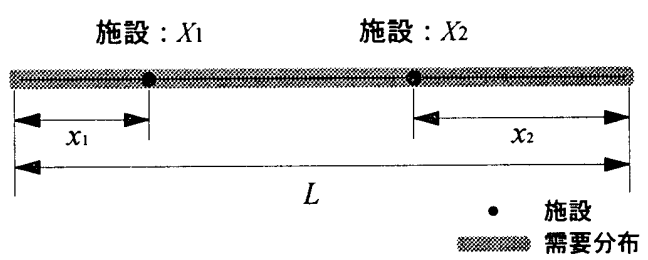

図 2 線分上の配置問題（サービス種類 3、施設数 2)

ここで $L, x_{1}, x_{2}$ を簡単に図 2 のように定めると、 $M_{i j k}$ は消元 て、すべての需要点における移動費用の総和 $F\left\{x_{1}, x_{2}\right\}$ は、(2)のよ うに表される。これから需要点の重み $\alpha, \beta$ 変数としたまま、(2) を最小とする $x_{1}, x_{2}$ の值（最適配置）を求めてみる。 $F\left\{x_{1}, x_{2}\right\}$

$=\frac{1+\alpha}{2} x_{1}^{2}+\frac{1+\beta}{2} x_{2}^{2}+\frac{\alpha}{2}\left(L-x_{1}\right)^{2}+\frac{\beta}{2}\left(L-x_{2}\right)^{2}+\frac{\left(L-x_{1}-x_{2}\right)^{2}}{4}$

ただし、 $x_{1}+x_{2}<L$

目的関数はその極值では勾配がゼロとなるから、(2)を展開して $x_{1}$, $x_{2}$ 双方でそれぞれ偏微分してそれらがゼロとなる条件を求めると、 簡単な連立方程式(3)となる。

$\left\{\begin{array}{l}\frac{\partial F}{\partial x_{1}}=\left(\frac{3}{2}+2 \alpha\right) x_{1}+\frac{1}{2} x_{2}-\left(\frac{1}{2}+\alpha\right) L=0 \\ \frac{\partial F}{\partial x_{2}}=\left(\frac{3}{2}+2 \beta\right) x_{2}+\frac{1}{2} x_{1}-\left(\frac{1}{2}+\beta\right) L=0\end{array}\right.$

これを解くと、(4)が成立する時に、 $F\left\{x_{1}, x_{2}\right\}$ は停留点となる。

$x_{1}=\frac{1+3 \alpha+\beta+4 \alpha \beta}{2(2+3 \alpha+3 \beta+4 \alpha \beta)} L$

$x_{2}=\frac{1+3 \beta+\alpha+4 \alpha \beta}{2(2+3 \alpha+3 \beta+4 \alpha \beta)} L$

なお目的関数 $F\left\{x_{1}, x_{2}\right\}$ のヘッセ行列は、(5)のようになり、

$H=\frac{1}{2}\left(\begin{array}{cc}3+4 \alpha & 1 \\ 1 & 3+4 \beta\end{array}\right)$ 


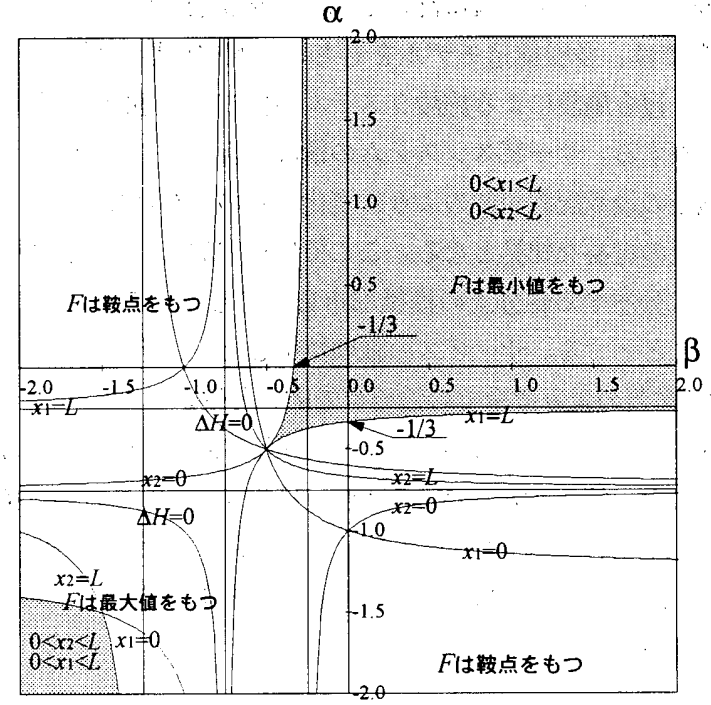

図 3 最適解が線分上に存在するための条件
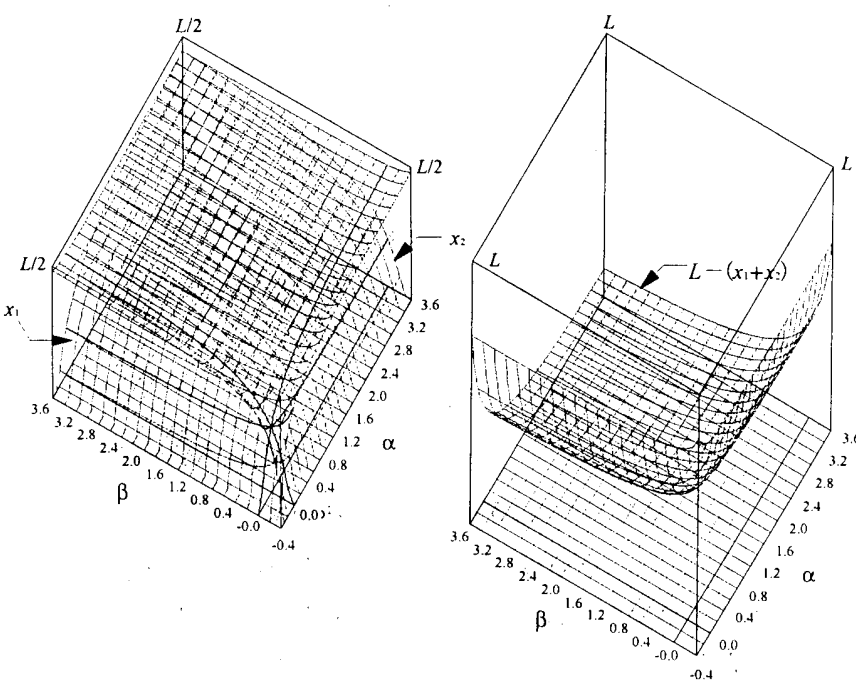

図 4

図 $4 \alpha, \beta$ を変数とした場合の最適解 $\left(x_{1}, x_{2}\right)$

図 $5 \alpha, \beta$ を变数とした場合の最適解における 2 施設の間隔 $\left(\mathrm{L}-x_{1}-x_{2}\right)$ 停留点の判別式は(6),(7),(8)のようになる。

$\Delta H=\frac{\partial^{2} F}{\partial x_{1}^{2}} \frac{\partial^{2} F}{\partial x_{2}^{2}}-\frac{\partial^{2} F}{\partial x_{1} \partial x_{2}} \frac{\partial^{2} F}{\partial x_{2} \partial x_{1}}=3 \alpha+3 \beta+4 \alpha \beta+2$

$\frac{\partial^{2} F}{\partial x_{1}^{2}}=\frac{3}{2}+2 \alpha$

$\frac{\partial^{2} F}{\partial x_{2}^{2}}=\frac{3}{2}+2 \beta$

つまり、(6)>0 かつ $(7)>0$ から $(8)>0$ で $F\left\{x_{1}, x_{2}\right\}$ は最小值をも ち、 $(6)<0$ かつ $(7)<0$ かつ $(8)<0 て ゙ ~ F\left\{x_{1}, x_{2}\right\}$ は最大值をもつ。

また、最小解が線分上に存在するための要件を(6)〜(8)を用いて調 べ、その条件を $\alpha-\beta$ 平面上で表すと、図 3 のようになる。最小解が 線分上に存在するためには、 $(\alpha, \beta)$ が図 3 における右上の網掛け の領域にある必要がある。

図 3 によれば、サービス $S_{1}, S_{3}$ に対する需要 $\alpha, \beta$ が負であって も、 $F$ を最小とする最適配置は線分上に存在する場合があることが 分かる。「負の需要」には色々な解釈が可能であろうが、正の需要 が正の効果に対する要求であるとすれば、負の需要は負の効果に対

する要求といえるだろう。負の効果には、たとえば下水処理場や清 掃工場などで行われるサービスの影響がそれに該当するであろう。 これらの施設は、都市には必要不可欠な施設であるが、近隣の住民 にとっては悪臭、塵埃、各種污染など負の効果を持ち、通常の施設 とは逆に、近隣の住民はそれらが近くに立地することを好まない。

前章で設定した問題は、あるサービスを得るために必要な移動 費用の総和最小化をめざすのであるが、負の効果を持つ施設につい ては、距離の増大とともに減少する負の効果の総和を最小化すると 考えればよい。例えば、迷惑施設との距離が小さいことによる「負 の効果」を「不満度 (あるいは迷惑度)」と解釈とし、逆に好まれ る施設への移動距離が大きいことによる「負の効果」を同様に「不 満度」と解釈すれば、この問題は「不満度の総和」を最小化する問 題とも言い換えることもできる注(4)。図 3 の結果では、下水処理場 や清掃工場といったいわゆる、「迷惑施設」の配置計画の場合でも、 近くに立地することが好まれる施設と複合した施設を計画すれば、 需要分布の存在する領域の内部に最適配置を見つけることができる ことを意味する。これまで迷惑施設は、他の行政区や他の行政区と の境界部の人口が少ない地域に計画され、隣接する他の行政区の住 民にとっては一方的に迷惑を押しつけられるケースも多い。そして それが問題となるケースが多々としてある。しかし此処での結果は、 迷惑施設と好まれる施設の複合を行えば、一定の範囲で自らの行政 区内部での最適な迷惑施設の配置計画の可能性があることを理論的 に示唆している。たとえば、下水処理場と公園との複合や、清掃工 場や電为施設にスポーツ施設やコミュニティ施設を複合（あるいは 併設）する計画などが考えられるが、これらは市街地に迷惑施設を 配置する際にすでに現実に実施されている計画例でもある。

つぎに、 $-0.4<\alpha<3.6,-0.4<\beta<3.6$ の範囲で $F\left\{x_{1}, x_{2}\right\}$ を最小值とする $x_{1}, x_{2} \cdot$ の最適解を 3 次元で表すと、図4のような曲面となり、最適解 の施設 $X_{1}$ と施設: $X_{2}$ の間隔 $\left(L-x_{1}-x_{2}\right)$ は図5のような曲面となる。

図 4,5によれば、 $\alpha, \beta$ ともに増大すれば $x_{1}, x_{2}$ も増大して $L / 2$ に 漸近し、中央部分に凝集した配置となることがわかる。:共通するサ 一ビス $S_{2}$ に対する需要は $w_{2}=1$ で不変であるから、 $\alpha, \beta$ が大きい ということは施設 $X_{1}$ と施設 $X_{2}$ のサービス内容の共通部分が小さ いことになる。つまり、2つの複合施設のサービス内容が相異なる 場合には、 2 施設の間隔は小さく、中央部分への凝集した配置が優 れていることになる。また逆に、 $\alpha, \beta$ が小さい場合には、逆に共通 するサービスが大きく、2つの複合施設が類似しているということ であるが、そのような場合には間隔の大きい配置が優れていること になる。要するに、施設 $X_{1}$ と施設 $X_{2}$ が類似した複合施設の場合 には、相互に離れた配置が優れており、相異なる複合施設の場合に は近接した配置が優れているということがいえる。

参考までに、需要が負の場合の最適配置についてもう少し詳細に 分析しておく。より単純に、負の需要に対するサービスは、片方の 施設のみで行われることと仮定し、 $\beta=0$ として表 5 のようなシス テム構成の 2 施設の最適配置を考える。つまり複合施設は $X_{1}$ のみ

表 5 負の需要に対するサービスが 1 種類の場合

\begin{tabular}{|c|c|c|}
\hline サ-ビスの種類 & $S_{\perp}$ & $S_{2}$ \\
\hline 需要点の重み & $\alpha$ & 1 \\
\hline 施設 $X_{1}$ & $\bigcirc$ & $\bigcirc$ \\
\hline 施設 $X_{2}$ & & 0 \\
\hline
\end{tabular}


である。このときの最適解は(9)となり、

$x_{1}=\frac{1+3 \alpha}{2(2+3 \alpha)} L, \quad x_{2}=\frac{1+\alpha}{2(2+3 \alpha)} L$

$0 \leqq x_{1}, x_{2} \leqq L$ に最適解が存在する条件を調べてみると、

$\alpha \geqq-1 / 3$

が必要十分条件であることが判る。ちなみに、サービス $S_{1}$ の需要

量 $\alpha$ を変えたときの最適配置を調べてみると、(9)から

$\alpha=-1 / 3$ の場合は、

$$
\begin{aligned}
& x_{1}=0, \quad x_{2}=L / 3 \\
& x_{1}=x_{2}=L / 4, \\
& x_{1}=L / 2, \quad x_{2}=L / 6
\end{aligned}
$$

$\alpha \rightarrow \infty$ 場合は、

となる。

すなわちサービスの重みが負の場合にも $-1 / 3$ より大きければ、 最適配置が領域の内部に定まることになる。この例題では、迷惑施 設が距離 1 だけ近くにあるときに増大する不満度が、好まれる施 設が距離 1 だけ遠くにある時の不満度の増分に対して対して、1／ 3 より小さい場合のみ領域内に配置可能であると解釈することもで きる。また $1 / 3$ に近づくほど境界部分に配置しなければならない。

これまで幾つかの論文で、迷惑施設の最適配置とその可能性に ついて幾つかの研究がなされてきたが 9,10,11,12)、全ての住民に敬遠 される施設など、サービスに対する需要の総和が負となる場合には、 迷惑施設を単体で配置するとすると、無限遠に配置する時に最適と なることが数理的に証明されており、有意な立地点を求めることは できず、領域の端でもっとも遠い場所（たとえば他の行政区との境 界部など）が最適立地点であるとされてきた ”。しかしそのように 他の行政区の住民に迷惑を押しつけるような計画が好ましくないこ とは言うまでもない。上の結果は、需要の総和が負であるサービス を行う施設であっても、工夫をして、他の好まれる施設と一体的に 計画して複合施設として配置を検討すれば、領域内に最適配置を見 つけることが一定の範囲で可能であることを示すものといえる。

また、この種の複合については「施設配置における公平性」と いう観点からもその有用性を評価できる。従来から、迷惑施設近隣 の一部の住民だけが迷惑を被ることに対する不公平感が問題となっ ているが、迷惑施設と好まれる施設を複合的に計画することにより、 迷惑施設が近くにあることによる不公平性を解消可能であるという こともできる。施設配置計画における公平性を実現する手法には 様々な方策が考えられるが、施設配置において公平性の向上を図る 1 つの手法として、この様な複合による方法が有効となりうること がわかる。

\section{5. 発見的解法}

前章では 1 次元の線分上の模擬都市における 2 施設の最適配置 とその存在条件を解析的に求めたが、2 次元以上の平面で最適配置 を解析的に求めることはできない。そこで再び(1)の問題にもどり、 2 次元以上の空間で複数個の施設の最適配置を求める発見的解法を 示しておく注(5)。(1)の目的関数の $\left\{\boldsymbol{x}_{i}\right\} に お け る$ 最急降下方向は、(14) のように表される。

$$
-\nabla F\left\{x_{i}\right\}=\sum_{i} \sum_{j} \sum_{k} M_{i j k} w_{j k}\left\|y_{j}-x_{i}\right\|^{-1}\left(y_{j}-x_{i}\right)
$$

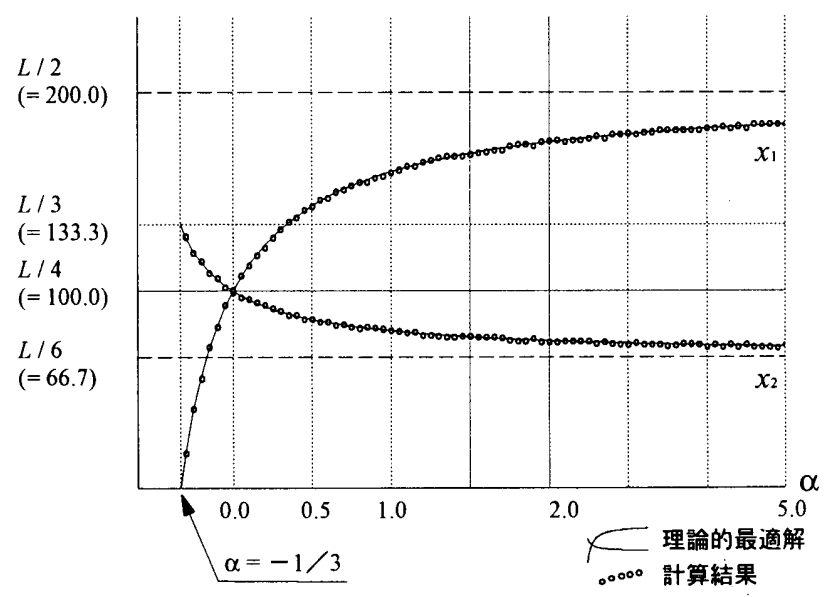

図 6 理論的な最適解本研究の解法による収束解

$x_{i}(t+1)=x_{i}(t)+h \varepsilon(t) M_{i j k} w_{j k}\left\|y_{j}-x_{i}(t)\right\|^{-1}\left(y_{j}-x_{i}(t)\right)$

需要点 $\boldsymbol{y}_{j}$ をランダムな順番で選択して、(15)の漸化式を用いてす心゙ ての添え字 $k$ についてランダムな順番で $y_{j}$ を含む目的関数の構成 要素の降下方向へ $x_{i}$ を移動させる。全ての $y_{j}$ が一巡して 1 回の学 習が終了した時点で $\boldsymbol{M}_{i j k} 、 h$ を更新して繰り返す。学習係数 $\varepsilon(t)$ を ゼロに漸近させることで目的関数は極小值に収束する。

この解法で最適解が得られることを検証しておく。前節の問題に 適用して、 $\beta=0$ の条件下で $\alpha$ を $1 / 3$ から増大する方向に变化さ せたときに、最適解と一致する解が得られることを示す。 $L=400$ として総数 401 の需要点が線分上に均等に分布するとする。 $\alpha$ の 最小値を -0.3 として、0.05 間隔に 5.0 までの解を計算した注(6)。 図 6 では、理論的最適解を曲線で示し、計算結果をプロットして いる。図から明らかなように、上の解法によって主最適解が得ら れることか確認できる注(て。

\section{2 次元平面における最適配置の分析}

最後に、2 次元平面における最適配置を例示し、3 章で線分上の 最適配置問題の分析によって得られた知見を再確認しておく。2 次 元の場合には、1 次元の問題ように解析的に最適配置を演繹するこ とができないので、幾つかの配置例を示して、システム構成と最適 配置の関係について洞察を深める。ただし多層構造モデルは一般的 なモデルであり、全ての可能な構成に対応して配置例を示してそれ を分析することは不可能である。そこで特徵的な例として、(1)多 数のサービスを複合して多様な複合施設を構成しそれらを配置する 場合、(2)負の需要に対するサービスを含む施設システムを構成し それらを配置する場合の 2 事例において最適配置の計算例を示し、 システム構成が異なる時の最適配置の比較を通して、最適配置とシ ステム構成の関係について考察を加える。

\section{1. 多様な複合施設の最適配置}

3 つのスポーツ施設の例で考える。まず 3 つの施設で行われる サービスが全て同じで何も複合されていない場合を想定する。例え ばそのシステム構成は表 6 のように整理できるとする。ここでは 仮に、サービスの内容を公共プールとしよう。 


\begin{tabular}{|l|c|}
\hline \multicolumn{2}{|c|}{ 表 6 サービスが 1 種類で施設が全て同じ場合 } \\
\hline サービスの種類 & 公共プール \\
\hline 施設 $X_{1}$ & $\bigcirc$ \\
\hline 施設 $X_{2}$ & $\bigcirc$ \\
\hline 施設 $X_{3}$ & $\bigcirc$ \\
\hline
\end{tabular}

次に、スポーツ施設が複合施設で、それぞれ特色のある多様なサ 一ビスを行っている場合を想定する。その施設内容を詳しく分類し て、たとえば表 7 のような多層構造モデルとして記述できるとし よう。施設 $X_{1} \sim X_{3}$ はどれも複合施設であり、そのサービス内容は 互いに異なっている。

表 7 椱合化により多様な施設システムを構成する場合

\begin{tabular}{|c|c|c|c|}
\hline $\begin{array}{c}\text { サ-ビスの } \\
\text { 種類 }\end{array}$ & 体育館 & $\begin{array}{c}\text { エア听ク } \\
\text { ス・スダ゙オ }\end{array}$ & $\begin{array}{c}\text { 公共 } \\
\text { プール }\end{array}$ \\
\hline 施設 $X_{1}$ & & $\bigcirc$ & $\bigcirc$ \\
\hline 施設 $X_{2}$ & $\bigcirc$ & & 0 \\
\hline 施設 $X_{3}$ & $\bigcirc$ & $\bigcirc$ & \\
\hline
\end{tabular}

表 6,7 のように施設のサービス構成が異なる場合にそれぞれの最 適配置を示し、施設サービスの複合化とそれによる多様化が進むと、 最適配置は需要分布の中心部への凝集型となることを例証する。こ こでは正方形の領域に需要点は均等に分布していると仮定し、需要 の重みは全てのサービスについてどの需要点でも 1 であると仮定 する。最適配置は、それぞれ図 7,8のように求められる注(8)。

まず表 6 のように施設が全て同じ場合では、図 7 のように 3 施 設がほほ均等に配置されるような最適配置となる。一方、表 7 の ように、1つの施設で数種類のサービスを行い、それぞれの施設で サービス内容の異なる特色のある施設としてシステムを構成する場 合では、最適配置は図 8 のように、図 7 の配置に比べてやや中心 部への凝集型の配置となっている。つまり、3 章で明らかにしたよ うに、各施設で行われるサービスの共通部分が相対的に小さくなる ように施設の多様化・複合化がなされると、施設の配置は中心部で 近接した凝集型の配置の方が優れた配置となるという性質があるこ とが確認できる注(9)。

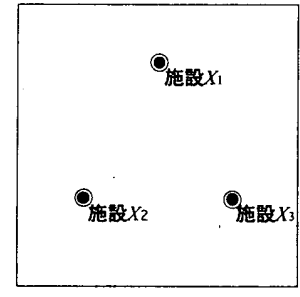

図 7 表 6 のシステムの最適配置

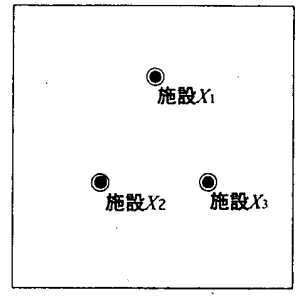

図 8 表7のシステムの最適配置

\section{2. 迷惑施設を含む最適配置}

まず表 8 のような施設システムを仮定する。 3 施設を配置する場 合に 1 施設のみ負の需要に対するサービスも行うこととする。す なわち複合施設は $X_{1}$ だけである。

サービス種類を $\left\{S_{1}, S_{2}\right\}$ とし、3つの施設でこれらのサービスを提 供する。ただしサービス $S_{2}$ については、すべての需要点で負の需 要があるとする。公共プールに対する需要の重みは全ての需要点で
1、清掃工場に対する需要は全ての需要点で $\alpha .(\alpha<0)$ とする。 この問題設定は、需要点から距離 1 のプールに対する不満度を 1 、 距離 1 の清掃工場に対する不満度を $\alpha$ と設定したと解釈しても良い。

表 8 1施設で負の需要のサービスを行う場合

\begin{tabular}{|l|c|c|}
\hline \#-ビスの種類 & $\begin{array}{c}\text { 公共プ } \\
N\left(S_{1}\right)\end{array}$ & $\begin{array}{c}\text { 清 掃 } \\
\text { 場 }\left(S_{2}\right)\end{array}$ \\
\hline 需要点の重み & 1 & $\alpha$ \\
\hline 施設 $X_{1}$ & $\bigcirc$ & $\bigcirc$ \\
\hline 施設 $X_{2}$ & $\bigcirc$ & \\
\hline 施設 $X_{3}$ & $\bigcirc$ & \\
\hline
\end{tabular}

まず $\alpha=-0.1$ と設定した場合の最適配置を図 9 に示す。ゴミ処 理場を複合する施設では領域の端の方に最適配置が定まる。さらに $\alpha=-0.14,-0.15$ に設定した場合の最適配置を図 10,11 に示す。 $\alpha=-0.14$ ではゴミ処理施設を併設する施設はさらに端の方に最適 配置が定まる。 $\alpha=-0.15$ にすると最適配置は領域の内部には求め られない注(10)。

つぎに、表 9 のように施設 2 でも負の需要に対するサービスを 行う場合の最適配置を求める。複合施設は $X_{1}, X_{2}$ の 2 施設である。

表 92 施設で負の需要のサービスを行う場合

\begin{tabular}{|c|c|c|}
\hline サービスの種類 & $\begin{array}{l}\text { 公共 } 7^{\circ}- \\
n\left(S_{1}\right)\end{array}$ & $\begin{array}{l}\text { 清 掃 I } \\
\text { 場 }\left(S_{2}\right)\end{array}$ \\
\hline 需要点の重み & 1 & $\alpha$ \\
\hline 施設 $X_{1}$ & 0 & 0 \\
\hline 施設 $X_{2}$ & 0 & 0 \\
\hline 施設 $X_{3}$ & 0 & \\
\hline
\end{tabular}

$\alpha=-0.10, \alpha=-0.15, \alpha=-0.30$ の場合の最適配置を図 $12,13,14$ に示す。この場合は、 $\alpha=-0.30$ でも領域内に最適配置が定まるこ とが分かる。このように、一般に負のサービスを行う施設数がその 他の施設数に比べて少ない場合には、 $\alpha$ 值がより狭く限定された 範囲でしか最適配置を見つけられないのに対し、負のサービスを行 う施設数が多い場合には、最適配置を計画する際に $\alpha$ の大きさの

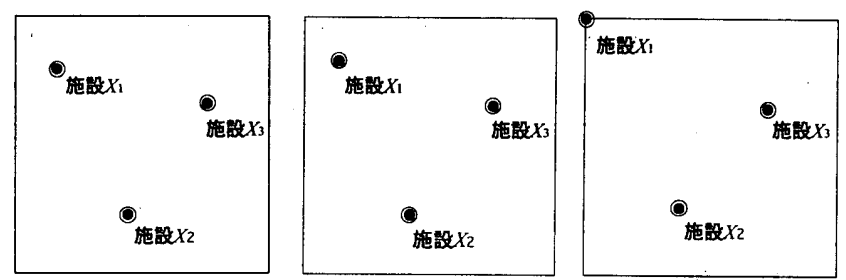

図 $9 \alpha=-0.1$ の最適配置 図 $10 \alpha=-0.14$ の最適配置 図 $11 \alpha=-0.15$ の最適配置 （表 8 による負の需要と正の需要に対する 3 施設の最適配置）

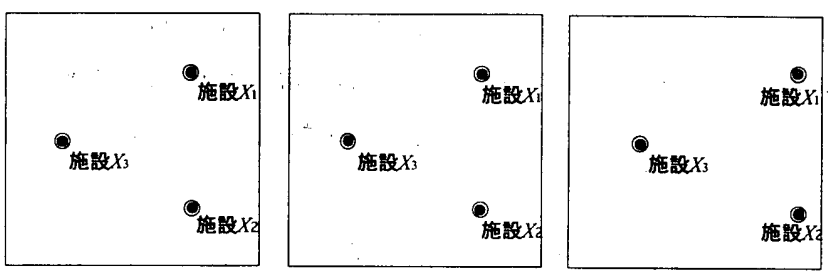

図 $12 \alpha=-0.1$ の最適配置 図 $13 \alpha=-0.15$ の最適配置 図 $14 \alpha=-0.3$ の最適配置 （表 9 による負の需要と正の需要に対する 3 施設の最適配置） 
許容範囲が大きくなることが分かる。したがって、喜ばれる施設と の複合化によって迷惑施設の最適配置を見つけようとすれば、その ためには負の需要に対するサービス機能を分散し、つまり巨大な迷 惑施設を 1 力所にまとめて建設するのではなく小さな迷惑施設を 数力所に分けて建設する方が、最適な配置を見つけられる可能性が 高いことが分かる。

\section{7. おわりに}

本研究では、施設配置計画のシステムモデルにおいて多層構造 モデルを提案し、多層構造を有する施設群の施設配置についてその 数理的計画法を提案するとともに、複合施設の構成とその最適配置 に関係について分析した。本研究による成果を要約すると、

1. 古典的なとエラルキーモデルに限定されない多様な施設配置 計画を可能とするモデルとして多層構造モデルを提案したこと。

2. 多層構造モデルを用いた施設配置問題として、多点のウエー バー問題に多層構造モデルを適用した場合の最適配置について、数 理的計画法を示したこと。

3. 施設システムと施設の最適配置の分析として、第 1 に、施設 の複合化による多梯化が進むと都市の中心部への凝集的な配置が優 れた配置となる傾向があることを例証し、第 2 に、迷惑施設と喜 ばれる施設を複合的に計画・配置する工夫によって、迷惑施設の限 られた領域での最適配置が可能であることを例証したこと。 などが挙げられる。

好まれる施設と迷惑施設を複合（あるいは近接）して配置する という方法は、不公平感を解消する手段として現実にも行われてい る計画手法であるが、本研究では、数理的観点からもそれが計画可 能であることを論証し、その可能範囲を例示した。このような計画 手法は、施設配置において公平性を実現する方法の 1 つとなりう るものであり、その観点からも注目できる。もちろん施設配置にお いて公平性を実現する方法は、このような方法が唯一というわけで はなく、そのほかにも様々な計画方法が考えられる。別稿では、配 置計画に扔ける公平性について、他の方法による可能性を含めて体 系的に論じて報告する予定である。

\section{<補注>}

(1) 英語の“Hierarchy”について、国内では一般に「階層」という訳語 が当てられてきた。しかし日本語の「階層」という言葉は曖昧で、 “Hierarchy”の他にも “Stratum”, “Layer”などの意味もある。英語 の”Hierarchy”はツリー・ネットワークで記述される「階級構造」だ けを表し、その他の意味は含まれないので注意を要する。本研究で は、より篁密に「階級」という訳語を用いている。

(2) 大気污染・騒音・危険性などの要因により近くに立地することが疎 まれる施設を「迷惑施設：Obnoxious Facility」と呼ぶ。

(3) その他に、Mirchandani, P.B. ${ }^{8)}$ では、階級構造の一般化モデルとし て地域的包含-排他階級構造(Locally Inclusive-Successively Exclusive Hierarchy Model)という、ある地域内では包含階級的でありな がら地域間では排他階級的な施設システムのモデルの提案があるが、 単なる対象領域の拡大による一般化であるので省略している。

(4)このモデルを現実の迷惑施設の配置計画に援用するためには、不満 度 (あるいは迷惑度) の定量方法等についても具体的に検討する必 要があろう。

(5) 基本的に岸本 14,17)でその有効性が確かめられた解法の拡張による。 本稿では学習係数 $\varepsilon(t)$ 、調整係数 $h$ など説明を省略しているが、詳

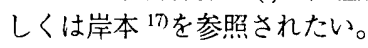

(6)学習係数は $0.95 /\left(1+t^{3} / 8000000\right)$ とし、学習回数 1000 回に設定 にした。

(7)最適解との微妙なズレがあるのは、理論解は一様連続な需要分布を 仮定しているのに対して、計算例では需要点を離散的に配置してい るからである。

(8)正方形の領域に合計 1600 点の需要点が $40 \times 40$ のグリッド状に均等 に分布しているとした。図 7〜14では表示を省略している。

(9) 上で示した最適配置の例は、各サービスに対する需要が全て均等に 分布していると仮定した場合の計算結果であって、地域ごとにサー ビスの種類によって需要が異なる場合には凝集する傾向はもう少し 稳やかに顕れるであろう。

(10)この設定では最適解は求められなかった。ここでは便宜的に、 境界部を含む対象領域内部に施設を配置するように制約条件を加え て最適解を求めている(図 11)。

<参考文献>

1) Christaller, W., Die Zentralen Orte in SudDeutschland, Verlag von Gustav, 1933,(都市の立地と発展,江沢譲爾訳, 大明堂, 1969)

2) 鈴木勉, 施設の最適な階層構造に関する考察, 日本都市計画学会学術 研究論文集, 25, 1990, 331-336

3) 奥貫圭一, 岡部篤行, 包含階層構造を持つ施設システムの最適化, 日 本都市計画学会学術研究論文集, 30, 1995, 565-570

4) Dökmeci, V.F., An Optimization Model for A Hierachical Spatial System, Journal of Regional Science, 13, 3, 1973, 439-451

5) Fisher, H.B., and Rushton,G., Spatial efficiency of service locations and the regional development process, Papers of the Regional Science Association Papers, 42, 1979, 83-97

6) Tien, J.M., El-Tell, K., and Simons, G.R., Improved Formulations to the Hierachical Helth Facility Location-Allocation Problem, IEEE Transactions on System, man, and Cybernetics, SMC-13, 6, 1983, 1100-1128

7) Narula, S.C., Hierarchical location-allocation problems: A classification scheme, European Journal of Operational Research, 15, 1984, 93-99

8) Mirchandani. P.B., Generalized Hierarchical Facility Locations, Transportation Science, 21, 2, 1987, 123-125

9) Tellier, L-N., Economique spatiale: rationalite economique de l'espace habite, Chicoutimi, Quebec: Gaetan Morin, 1985.

10) Tellier, Luc-Normand and Boris Polanski, The Weber problem : frequency of different solution types and extension to repulsive forces and dynamic process, Journal of Regional Science, 29, 1989, 387-405

11) Drezner, Z., Wesolowsky, G.O., The Weber Problem on the Plane with negative weights, INFOR, 29, 1990, 87-99

12) Chen,P.-C., et al., Weber's Problem with Attraction and Repulsion, Journal of Regional Science, 32, 4, 1992, 467-486

13）大澤義明,グループ利用施設の最適配置の頑健性について, 日本才 ペレーションズ・リサーチ学会論文誌, $30,3,1987,368-395$

14）岸本達也，連続平面上における離散的需要分布に対する基本的施設 配置問題の解法, 日本都市計画学会学術研究論文集, 32, 1997, 109114

15) 笠原一人, 古山正雄, 最短木および階層を有する木の長さに関する 考察, 日本建築学会計画系論文集, 504, 1998, 155-161

16) 岸本達也,「連続空間における施設の最適配置問題に関する研究」, 東 京大学博士学位論文, 1998

17）岸本達也, 距離のべき乗和を最小化する施設群の最適配置問題とそ の解法, 日本建築学会計画系論文集, 521, 1999, 301-308

18）岸本達也，利用者数の総和を最大化する施設の最適配置モデルー空 間相互作用モデルを用いた施設の配置計画法その 1 -, 日本建築学会 計画系論文集, 521, 1999, 227-235

19) 岸本達也, 期待焼損面積を最小化する消防施設の最適配置, 日本建 築学会計画系論文集, 522, 1999, 337-344 